\title{
Syirkah Amlak's Implications in Building Community Economic Independence (Analysis of Meranti Islands Regency, Riau Province)
}

\author{
Syahpawi, Amiur Nuruddin, Sri Sudiarti
}

\begin{abstract}
This research discusses Syirkah Amlak's Implications in Building Community Economic Independence in Meranti Islands Regency. Islam as the religion of rahmatan lil-'alamin regulates all aspects of the lives of its people. Syirkah Amlak is a maqasid syariah translation of property maintenance and an alternative in solving problems that have occurred in society, where poverty is caused by various factors, one of which is not having the capital to do business. The case that occurred in the Meranti Islands Regency was that inheritance was used as capital in building a business of economic independence, so far the community assumed that inheritance had to be divided based on the understanding of the meaning of the verses in the Qur'an and the hadith of the Prophet. In addition, researchers want to see the implications of syirkah amlak in building community economic independence from aspects of its Islamic principles. The research method used is a qualitative approach (in-depth interviews), sources are carried out by observation, interviews, documentation, history, and questionnaires. While analyzing the data the researcher used descriptive analytic (analytic descriptive research). The results of this study found that the implications of syirkah amlak in building the economic independence of the community have an impact on increasing income, labor, education, religion and blessings / salvation (al-falah), where there are most people who do syirkah amlak already able to develop industry and some again in the form of additional gardens in the Meranti Islands Regency.
\end{abstract}

Keywords: Implications, syirkah amlak, economic independence.

\section{INTRODUCTION}

Islam is a rahmatan lil-'alamin religion, this illustrates that humans have a very important role in life in the world as explained by Allah in the Koran, ${ }^{1}$ where human function is to regulate all aspects of human life in the wor

Revised Manuscript Received on July 22, 2019.

Syahpawia, Postgraduate S3 Students in the Department of Syari'ah Economics UIN Sumatera Utara Medan, Indonesia.

Amiur Nuruddinb, Professor of Sharia Economics at UIN Sumatera Utara Medan, Indonesia.

Sri Sudiartic, Head of Syari'ah Economics Study Program UIN Sumatera Utara Medan, Indonesia. ld and the hereafter. Human relations with humans are included in the scope of social relations, ${ }^{2}$ this is called human beings as social beings.

Islamic Economics is built based on three main filars namely Tawhid, Caliph and al-Falah. ${ }^{3}$ Islamic economic philosophy is based on the concept of triangle: the philosophy of God, man and nature based on the maqasid syari'ah. ${ }^{4}$ Islamic economics ${ }^{5}$ is upheld based on religious teachings given to humans to be carried out in life. ${ }^{6}$ According to Muhammad Nejatullah Siddiqi that the principle of Islamic economics is related to the problem of human relations with God, nature with its creatures, the emphasis given is the principle of monotheism and caliph. ${ }^{7}$

The Islamic economic system is an alternative to an institution that is free of usury, so the Islamic scholars and experts of Islamic economics have formed a profit and

2 Jan Pronk, "Globalization: A Developmental Approach", in Jan Nederveen Pieterse (ed), Global Future, Shaping Globalization, London: Zed Books, 2001, p. 43.

3 Khurshid Ahmad, Studies in Islamic Economics. Leicester, U.K: The International Centre for Research in Islamic Foundation, 1980, pp. 270-271.

${ }^{4}$ Ahmad al-Risuni, Nadhariyah al-Maqasid 'Inda alImam al-Syatibi, Virginia: The International Institute of Islamic Thought, 1995, p. 60.

${ }^{5}$ The principle of Islamic economic philosophy has a different understanding from the principles of Islamic economics, but both have the same purpose. It is very difficult to clearly distinguish between the two. Therefore, all the cases discussed in the philosophy of Islamic Economics are also discussed in the principles of Islamic economics.

6 Monzer Kahf, "Islamic Economic System - A Review" in Aidit Ghazali dan Syed Omar (ed), Reading in The concept and Methodology of Islamic Economics. Pataling Jaya: Pelanduk Publications, 1989, p. 72.

${ }^{7}$ Muhammad Nejatullah Saddiqi, Muslim Economic Thinking: A Survey of Contemporary Literature. Leicerter, United Kingdom: The Etsdama, Foundation, 1989 , p. 1. 


\section{Syirkah Amlak's Implications in Building Community Economic Independence (Analysis of Meranti Islands Regency, Riau Province)}

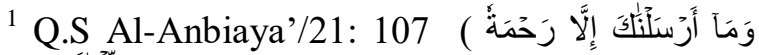

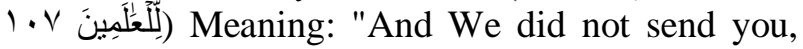
but to (be) a mercy to the universe."loss sharing system, this is the basis of mudarabah and musyarakah principles. ${ }^{8}$ Mudharabah is one of the contracts or forms of cooperation between owners of capital and someone who is an expert in trade. ${ }^{9}$ While musharakah is a partnership contract or a bond of cooperation carried out by two or more people in trade. ${ }^{10}$ Both principles are the basis for all Islamic economic activities where money, land and labor can be used as capital. ${ }^{11}$

Musyarakah is a product to get benefits that can be shared with those who do partnership based on the agreement of both parties in making an agreement, whether it follows the level of capital donated and vice versa if there is a loss then it will be borne by each party based on the level of capital each of them as business partners. $^{12}$

The reality that occurred in the field in this study was that the inheritance of inheritance was used as capital in building the economic independence of the community in Kepualaun Meranti Regency, Riau Province, which provided a different approach in building the community's economic independence business.
\end{abstract}

\section{Theoretical Foundation}

The existence of property (al-mal) is a necessity in human life. Without human property is not able to meet the needs of his life both primary (dharuriyah), secondary (hajiyah), and special needs (tahsiniyah). ${ }^{13}$ Islam recognizes individual ownership, joint ownership (syirkah), and state ownership. But when Islam recognizes individual ownership of property, Islam also provides a special concept in its management, namely

${ }^{8}$ M. Umer Chapra (1985), Towards a Just Monetary Sistem. Terj. Ismail bin Omar. Kearah Sistem Kewangan yang Adil. Kuala Lumpur: Dewan Bahasa dan Pustaka, 1990 , p. 60.

9 Nasrun Haroen, Figh Muamlah. Jakarta: Gaya Media Pratama, 2000, p. 175.

${ }^{10}$ Ibid., p. 166.

${ }^{11}$ Islam seeks to build a society based on honesty and justice. Justice in this context has two dimensions: first the investor has the right to get a reward, but the reward must be in accordance with the risks and effort that is done, the two benefits are from the capital business. So, what is forbidden in Islam is predetermined profit. The predetermined profit sharing in Islam is the profit and sharing ratio, not the level of profit. Mervyn K. Lewis dan Lativa M. Algaoud, Islamic Banking. Massachusetts: Edward Elgar, 2001, p. 64.

12 M. A. Mannan, Islamic Economics; Theory and Practice, Cambridge: Houder and Stoughton Ltd, tt, p. 182.

13 Abdur Rahman Ibn Khaldun, Mugaddimah, Ttp: Matbaah al-Azhariyah, 1348 H, pp. 340-341; Abdul Wahab Khalaf, Mashadir al-Tasyri' fi Ma la Nashsha Fiki, (Ttp: Ma'had al-Dirazah al-A'rabiyah), p. 4. the concept of khilafah (God's caliph on earth). This is what makes the owners of the property must be consistent with the provisions of God relating to the management of property as a consistent representative and caliph in following the will of the giver of the mandate or the person who gives the task of the caliphate (muwakkil and mustakhkif). ${ }^{14}$

Protection of property can be done by positive protection (min janib al-wujud) and negative protection (min janib al-'adam). Maqasid syari'ah is related to wealth very much, but the most important of them is the mabdi attadawul, al-wukai fil amwal, and al-'adalah fi alamwal. ${ }^{15}$ As for how to protect property by preventing tyranny, the Shari'ah establishes two models of sanctions. First, sanctions imposed by sharia such as sanctions applied to robbers and thieves. Second, sanctions that are not stipulated directly by the Shari'ah, such as ta'zir for corruptors and those who destroy and eliminate capital.

Shari'ah Maqasid is basically to realize benefit and reject the interpretation, not to mention Islamic inheritance law which is also a shari'ah law. The division of inheritance is directly related to property, if it is not given based on the applicable provisions, it will be very easy for disputes to occur among heirs. In addition, Islamic inheritance law embodies the benefits of family members in community life. This is because the division of inheritance in Islam is not only shown to certain people from family members without giving to other family members. ${ }^{16}$ The implementation of Islamic inheritance law means running Islamic law. This shows the submission of a servant to the Lord. Allah says: Meaning: (those laws) are the provisions of Allah ... (Q. S. Annisa: 13-14). Also explained in the hadith of the Prophet Muhammad: Meaning: Divide the inheritance among heirs according to the book of Allah. (HR. Muslim and Abu Daud).

Islamic inheritance law aims to maintain the integrity and harmony of families. It is hoped that there will be no division between families because fighting for inheritance, as well as guaranteeing the heirs can live well after being left by the heir. Islamic inheritance law also aims to protect property, especially with the distribution of property, so that it is expected that there will be no accumulation of property to someone. Assets can be distributed fairly to all heirs.

TABLE (1). The Relationship of Islamic Inheritance with the Maqasid Syari'ah.

14 Rif'at Sayyid al-Iwadhi, Kitab al-Ummah fi alIstishad al-Islamy al-Murtakaza al-Tauzi' al-Istimar, p. 75.

${ }^{15}$ Yusuf Hamid al'Alim, al-Maqashid al-'Ammah Li al-Syari'ah al-Islamiyah, Horndon: al-Ma'had al- 'Alami Li al-Fikiri al-Islamy, 1991, p. 477.

${ }^{16}$ Muhammad Syah Ismail, Falsafah Hukum Islam, Jakarta: Bina Aksara, 1992, p. 235. 


\begin{tabular}{|c|c|c|c|}
\hline No & $\begin{array}{c}\text { Function/ Wisdom of Inheritance } \\
\text { Distribution }\end{array}$ & $\begin{array}{l}\text { Maslahah aspect } \\
\text { Protected }\end{array}$ & $\begin{array}{c}\text { Maslahah } \\
\text { Rating }\end{array}$ \\
\hline 1 & Submission Symbol to God & $\begin{array}{l}\text { Protection of religion in the } \\
\text { implementation of inheritance law }\end{array}$ & Hajiyat \\
\hline 2 & $\begin{array}{l}\text { As a means of maintaining family } \\
\text { integrity }\end{array}$ & Protection of offspring & Hajiyat \\
\hline 3 & $\begin{array}{l}\text { As a means of distributing assets } \\
\text { fairly }\end{array}$ & Protection of property & Hajiyat \\
\hline 4 & $\begin{array}{l}\text { As a means of safeguarding family } \\
\text { needs }\end{array}$ & Protection of family education & Hajiyat \\
\hline
\end{tabular}

Syirkah is generally divided into two types, namely syirkah ownership rights (syirkah amlak) and syirkah transactions (syirkah uqud). Syirkah Amlak is a collaboration between two or more people in possession of a property because of one of the reasons for ownership, such as buying and selling, grants or inheritance. ${ }^{17}$ Syirkah Amlak is divided into two types, namely: 1. Ikhtiyariyah, cooperation based on the choice of people who are associates, namely unions that arise due to legal actions of people in association, such as two people who agree to buy an item, or those who receive a grant, will or waqf and become theirs in association. In this case the transferable treasure became union property for both of them. 2 . Ijbariyah, a union that arises forcibly, not on the wishes of a person in association, ie something that is determined to belong to two or more people without their will. For example, the inheritance they receive from a deceased person, the property becomes the joint property of his heirs, this is one way to get partnership capital in developing the economy for economic independence.

The association of syirkah can form economic independence as an embryo of a Muslim's behavior as khalifatullah fil $\operatorname{ardh}^{18}$ as a basis of partnership can be seen in the Qur'an as the word of Allah SWT, which means: "For men there is the right of the inheritance of the mothers and their relatives, and for women there is the right (also) of inheritance mother-father and relatives, whether little or many according to the part that has been determined. ${ }^{19}(\mathrm{Q}$. S: an-Nisa / 4: 7.) And "Then they allied in one third". ${ }^{20}$ (Q. S: al-Nisa '/ 4: 12).

In principle Syirkah is different from other economic systems. The differences that exist not only lie in the absence of interest practices, but also differ in terms of their formation transactions, their operations and the formation

17 Abdullah al Mushlih dan Shalah ash Shawi, Fikih Ekonomi Keuangan Islam, terj. Abu Umar Basyir. Judul asli: Ma ia Yasa'ut Tajiru Jahluhu, Jakarta: Darul Haq, 2004 , p. 148.

QS: $\quad$ Al Baqarah/2: 30:

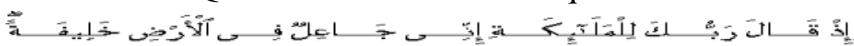

: "Remember when your Lord said to the angels:" I will make a caliph on earth. "

19 Departemen Agama RI, Al-Quran Dan Terjemahannya, Bandung: PT Diponogoro, 2014.

${ }^{20}$ Ibid. of profit and loss responsibilities. ${ }^{21}$ Whereas syirkah 'uqud is a partnership formed with the agreement agreement between those who have membership, consisting of: syirkah an Inan, syirkah mufawadhah, syirkah wujuh and syirkah' abdan. $^{22}$

Talk about syirkah is inseparable from the debates of the mujtahids, by adopting the maqasid sharia approach, where syirkah is one form of the sharia maqasid elaboration of the maintenance of property. Syirkah Amlak is one of the methods to get business partnership capital, both in the form of self-reliance and economic development. According to Agus Suryino, there are at least five partnership requirements to form development, including: Ability, Mutuality, Power, Resilience and Dependence. ${ }^{23} \mathrm{~A}$ development can be said to be successful if it is able to elevate as many people as possible in the order of economic life that is better and more feasible especially the independence of the economy in increasing welfare. ${ }^{24}$

The discussion of economic independence cannot be separated from the elements of education, religiosity and happiness. This can be seen from the opinion of Burnadib in Zainun Mu'tadin, defining independence as a state when a person has a competitive desire to progress for his own good, is able to take decisions and initiatives to overcome the problems at hand, ${ }^{25}$ have confidence in doing their duties, and are responsible for what they $\mathrm{do}^{26}{ }^{26}$ and the

${ }^{21}$ Faruq An-Nabahan, Sistim Ekonomi Islam: Pilihan Setelah Kegagalan Sistim Kapitalis dan Sosialis, Yogyakarta: UII Press, 2000. Cetakan Kedua, p. 68.

${ }_{22}$ Sayyid Sabiq, Figih Sunnah, Terj. Kamaluddin A. Marzuki, Bandung: Al Ma'arif, 1988, p. 176.

23 Agus Suryono, Pengantar Teori Pembangunan, Malang: Universitas Negeri Malang, 2004, p. 37.

${ }^{24}$ Sumodiningrat, Gunawan, Pemberdayaan Masyarakat dan Jaring Pengamanan Sosial, Yogyakarta: Ghalia Indonesia, 1999, p. 72.

25 Zainun Mu'tadin (2002), Kemandirian Sebagai Kebutuhan Psikologis pada Remaja, http://www.epsikologi.com/epsi/search.asp, diakses tanggal 27 April 2017.

26 Hill dan Holmbeck (dalam Collins, Gleason, \& Sesma, define independence as follows: "Autonomy refers not to freedom from others (e.g., parents), but freedom to carry out actions on one's own behalf while maintaining appropriate onnections to significant others". Collins, W. A., Gleason, T., \& Sesma, A. Jr., 1997, Internalization, Autonomy, and Relationships: Roment during Adolescence. dalam J. E. Grusec L. Kuczy'ski (Eds.), 571

Published By: 


\section{Syirkah Amlak's Implications in Building Community Economic Independence (Analysis of Meranti Islands Regency, Riau Province)}

ability to think and act without the help or influence of others, the ability to decide what should or is being done. ${ }^{27}$ Furthermore Ojameruaye defines independent economic development as a type of development that relies on humans and material resources from economic units. ${ }^{28}$ This concept prioritizes development and empowerment programs that are systematically designed so that individuals or communities are the subject of empowerment. $^{29}$

Independence based on solid monotheism is the identity of a Muslim, so that being able to appear as a caliph fi alardhi, he must even appear as a martyr 'ala al-nas. Therefore the value of monotheism as a belief can cause every Muslim to have the spirit of jihad as his work ethic. Independence for a Muslim is a symbol of the struggle for a very expensive spirit of jihad (fighting spirit). ${ }^{30}$

Then Spencer in Rofiq, stated that the characteristics of independence are as follows: First, being able to take the initiative. Second, able to overcome problems. Third, full of perseverance. Fourth, get satisfaction from his efforts. ${ }^{31}$

Handbook of Parenting and the Transmission of Values, New York: Wiley, 1997, pp.78-99.

27 "Self-reliance is defined by independence. It is the ability to think and act without the help or influence of others, the ability to decide what you should be or do. It is one of the bases of effective community development in Nigeria as it is in most of Sub-Saharan Africa. There is no gainsaying that the concept of self-reliance is positioned centrally within the discourse of community development and is linked to similar terminologies like self-help, mutualhelp, indigenous participation and rural development. Selfreliance encourages the need for people to improve their living conditions using home initiatives and resources at their disposal. This concept is being given great attention and considered as a new blueprint for community development". Idoma Kim, Muhammad Isma'il, "SelfReliance: Key to Sustainable Rural Development in Nigeria", ARPN Journal of Science and Technology, VOL. 3, NO. 6, June 2013.

${ }^{28}$ Ojameruaye, E. "Strategies for Self-reliant Economic Development of Urhobo land: A Paper Presented at the 5th Annual Conference of Urhobo Historical Society at PTI Conference Centre". Effurun, Delta: 2004. p. 12.

29 Shomedran, (2016), "Pemberdayaan Partisipatif Dalam Membangun Kemandirian Ekonomi dan Perilaku Warga Masyarakat (Studi Pada Bank Sampah Wargi Manglayang RT 01 RW 06 Kelurahan Palasari Kecamatan Cibiru Bandung)",

${ }^{30}$ Rizal Mustaqim, "Kemandirian Dan Pemberdayaan Ekonomi Berbasis Pesantren (Studi Atas Peran Pondok Pesantren Al-Ittifaq Kecamatan Rancabali Kabupaten Bandung Terhadap Kemandirian Eknomi Santri Dan Pemberdayaan Ekonomi Masyarakat Sekitarnya)", dalam Jurnal Ekonomi Syari'ah Indonesia. Volume I, No.2 Desember 2011, p. 68.

31 Rofiq, Romdin A., A. Icep Fadlil Yani dan R.B. Widodo, Pemberdayaan Pesantren Menuju Kemandirian dan Profesionalisme Santri dengan Metode Daurah Kebudayaan, Yogyakarta: Pustaka Pesantren, 2005, p. 76. The same thing expressed by Lindzery and Aronson said
According to Hubeis, independence will enable a person to improve his quality which includes aspects of quality of life, work, work, and thought. ${ }^{32}$ In line with this, Fonchingong and Fonjong stated that independence begins with understanding / thinking that considers themselves and their own resources as the main capital to achieve goals, then able to manage the resources they have, and able to meet their own basic needs. ${ }^{33}$ Poverty makes people more independent in fulfilling the needs of life so as to give birth to an effort as an initiative in overcoming this holiness. ${ }^{34}$

According to Galtung et al, Independence is considered not "only a necessity but a matter of survival." Indigenous community development initiatives have increased. The size, scope and function of an insightful development strategy, shows an important feature as an appropriate function in economic development. ${ }^{35}$

While economic independence According to Avilliani is defined as a nation, society or family that has economic resilience to various kinds of crises and does not depend on

that the characteristics of one's independence are: First, it is relatively rare to ask for protection from others. Second, show initiative and strive to pursue achievement. Third, show confidence. Fourth, always want to stand out.

${ }^{32}$ Hubeis, H.V.S. (2002). Challenges and Prospects of Information and Communication Technology in Regional Autonomy. Dalam Pambudy, R., dan Adhi, A.K. (ed). Pemberdayaan Sumber Daya Manusia Menuju Terwujudnya Masyarakat Madani, Bogor: Pustaka Wirausaha Muda,tt, pp. 13-23.

${ }^{33}$ Fonchingong, C.C., dan Fonjong, L.N. (2003). "The Concept of Self-Reliance in Community Development Initiatives in The Cameroon Grassfields". Nordic Journal of African Studies, Vol. 12(2), pp. 196-219.

${ }^{34}$ Njoh, A. 2002. "Barriers to Community Participation in Development Planning: Lessons from the Mutengene (Cameroon) Self-help Water Project." Community Development Journal, 37(3): pp. 233-248; Gooneratne, W. and Mbilinyi, M. (eds.) 1992. "People's Responses to the Economic Crisis in Eastern and Southern Africa." Reviving Local Self-Reliance. UNCRD, Japan.

${ }^{35}$ Galtung, J. et al. (eds.). Self-Reliance: a Strategy for Development. London: Bogle L'Ouverture publications. 1980, dalam. Charles c. Fonchingong \& lotsmart N. Fonjong (2003), "The Concept Of Self-Reliance In Community Development Initiatives In The Cameroon Grassfields," Nordic Journal of African Studies, 12(2): pp. 196-219; Acho-chi, C. 1998. "Sustainable selfdevelopment efforts in Cameroon grass fields." Development in Practice, 8(3): p. 366. Menurut Hyden, economic development with compassion where the obligation of city dwellers and villagers together in kinship and ethnic networks to contribute to maintaining survival, maintenance and development is the basis for achieving happiness in the world and the hereafter. Hyden, G. No Shortcuts to Progress: African Development Management in Perspective. (London: Heinemann, 1983), dalam. Charles c. Fonchingong \& lotsmart N. Fonjong (2003), "The Concept Of Self-Reliance In Community Development Initiatives In The Cameroon Grassfields," Nordic Journal of African Studies, 12(2): pp. 196-219. 
outsiders. ${ }^{36}$ Economic independence as stated by Hill and Holmbeck (in Collins, Gleason and Sesma) is that Autonomy does not refer to freedom from others (parents), but freedom to act on its own behalf while maintaining a connection that is appropriate for others. ${ }^{37}$

\section{RESEARCH METHODOLOGY}

The research method used is a qualitative approach (depth interview), data sources that are carried out by observation, interviews, documentation, historical. While analyzing the data of the researcher using analytic descriptive (analytic descriptive research).

\section{DISCUSSION}

Building economic independence depends on tradition or culture built on the consensus of local wisdom values. If local culture and wisdom are associated with business activities, it becomes an entity that cannot be separated. Business cannot be separated from the cultural values and social life of the people that are embraced. It cannot be contested, but must be correlated or even integrated. Therefore, understanding the values of local cultural wisdom becomes very significant in constructing Islamic economic fundamentals. ${ }^{38}$

Syirkah Amlak carried out by the community in the Meranti Islands Regency consists of several reasons which they stated, among others are: 1. Fewer Abandoned Assets (condition of property left behind not in large numbers), 2. Old Testament (Proverb). As experienced by one of the residents Meranti Pak Agus explained that all this happened due to the saying of our elders saying that: "all property / gardens are made for our children and grandchildren". Then followed by a will from his parents said that: "this property / garden must not be reduced (sold) but it increases nothing", this is what is one of the causes of the origin of the inheritance. ${ }^{39}$ 3. Seeing the Conditions that Occur in the Community Against the assets distributed To the heirs, there are cases that occur in the community that the assets divided faraidh to the heirs cause noise and even murder

${ }^{36}$ Avilliani. Kemandirian Ekonomi. UIN: Institute for Development of Economics and Finance. 2012, h. 6.

37 Hill dan Holmbeck mendefinisikan kemandirian sebagai berikut : "Autonomy refers not to freedom from others (e.g., parents), but freedom to carry out actions on one's own behalf while maintaining appropriate connections to significant others". Lihat, A. Jr. Collins, W. A. Gleason, T. \& Sesma, "Internalization, Autonomy, and Relationship: Development during Adolescence". Dalam J. E. Grusec \& L. Kuczynski (Eds), Handbook of Parenting and The Transmission Of Values. New York: Wiley, 1997, pp. 78-99.

${ }^{38}$ Juhaya S Pradja, Ekonomi Syariah, Bandung: Pustaka Setia, 2012, p. 176.

${ }^{39}$ Ibid. occurs among the heirs. ${ }^{40}$ 4. Conditions of Abandoned Heirs. The existence of heirs who are not capable in managing assets when distributed. ${ }^{41}$ 5. Keeping Assets (Asset) To Stay Intact as a Treasure of Local Wisdom. ${ }^{42}$

The application of Syirkah Amlak carried out by the people in Kepulauan Meranti Regency in building economic independence, among others: 1. Absolute Ownership of All Legacy Assets Used as Joint Ownership, where all the assets left behind are managed by one person only. $^{43} 2$. Ownership of a portion of inheritance which is used as joint ownership, assets that are economic (commercial) which are used as joint assets in their ownership, but the management remains only one person. ${ }^{44}$ 3. Joint Ownership In the Management of Some Legacy Assets, the shared property left behind is used by the heirs if necessary. ${ }^{45}$ and 4. Family Management, in this case the assets left behind are managed by family experts as business managers. ${ }^{46}$

The division of the business proceeds is divided based on kinship, this is carried out in large part by the heirs who conduct the ownership partnership. But there are also based on faraidh (each part) according to the rights they obtain then reduced by the processing costs of the assets of the results of the business.

Syirkah Amlak's implication in building economic independence in Meranti Islands Regency can be seen in the form of, among others: 1. Level of Education, this is as Pak Fuat said that having joint assets namely sago plantation and rubber plantation as inheritance of his parents although not in a large amount he managed to manage the property. The results of the management of the garden are used to meet the needs of his family everyday and the costs of education for his siblings. The results of the partnership's inheritance managed by Pak Fuat have now been able to complete 3 of his younger siblings in a high-level university, and another is continuing his tertiary

${ }^{40} \mathrm{Mr}$. John Patimura, Interview, as one of the legacy implementers, on June 22, 2018.

${ }^{41} \mathrm{Mr}$. Fuat, Interview, one of the men who manages his parents' land in Pelantai village on September 8, 2018

${ }^{42} \mathrm{Mr}$. Nong, Interview, one of the leaders and manager of inheritance in Sungai Tohor village on September 5, 2018

43 Mr. Nasaruddin, Interview, one of the estate managers in the fig wood village / linau river on June 22, 2018; Mr. Abdul Halim Al-Mahally, Interview, one of the owners of inheritance in Batang Malas village on May 25, 2018

${ }^{44} \mathrm{Mr}$. Rudi, Interview, one of the owners of inheritance in Semukut village on 31 August 2018

${ }^{45} \mathrm{Mr}$.Teh (Ismail), Interview, as one of the leaders and property managers in Sungai Tohor village on July 14, 2018

46 Mr. Agusnimar, Interview, one of the heirs and community leaders in Kepulauan Meranti Regency on May 14, 2018; Mr. Mahmudin, Interview, one of the plantation managers in the village of Lalang Tanjumgon September 6, 2018

Published By: 


\section{Syirkah Amlak's Implications in Building Community Economic Independence (Analysis of Meranti Islands Regency, Riau Province)}

education in Riau. ${ }^{47}$ 2. Income level, the profit from the results of the business that is managed is to meet their needs, such as the cost of daily living expenses, education costs, and other needs. Furthermore, according to Pak Agus's explanation that the development of the sago refinery business that they are doing can contribute to the absorption of labor for the surrounding communities and at the same time have an impact on increasing people's income.

Sungai Tohor Village, the community's income from the 14 sago refinery business produced 1.3 billion per month with a total of 700 tons of sagas per month. Whereas in Lalang Tanjung village the sago income from the joint property is approximately $1200-1500$ tons per month with an income of 3.5 billion per month. ${ }^{48}$ Apart from that, the community that used to not work now gets a job from the sago refinery industry, but has not been able to accommodate a large number of workers. 3. Workforce level, the number of workers accommodated from the sago refinery industry reached 150 people. 4. Industrial Improvement, the business has now developed into 16 sago refineries from the business results they manage together, the capital they earn is from the inheritance of their parents. $^{49} 5$. Level of Religiosity (obedience to God), this level of religiosity is measured from the results of the assets obtained used to pay zakat, infaqs of orphans, social assistance and other religious activities. and 6. Welfare Level (al-Falah), the level of prosperity seen in terms of the physical life of those who carry out syirkah amlak, the relationship between fellow family experts, fellow citizens, and the relationship with the creator (Allah).

\section{CONCLUSION}

The implementation of syirkah amlak in building economic independence can be taken several conclusions, including:

1. Background of the realization of the community in the Kepulauan Meranti Regency of Riau Province to conduct Syirkah Amlak, among others: Assets left behind a little (condition of property left not in large numbers), Wasiat (Proverb) parents, Seeing the conditions that occur in the community towards the property distributed to the heirs, conditions of the heirs left behind, and guarding assets (assets) to remain intact as a treasure of local wisdom.

2. The form of the application of syirkah amlak in building the economic independence of the community, among others: absolute ownership of all inheritance as joint ownership, ownership of a portion of inheritance which is used as joint ownership, joint ownership in the management of a portion of inheritance, and family management.

${ }^{47} \mathrm{Mr}$. Fuat, Interview, as one of the parents who carried out the parent property partnership on July 23, 2017

$48 \mathrm{Mr}$. Mahmudin, Interview, one of the plantation managers in Lalang Tanjung village on September 6, 2018

${ }^{49} \mathrm{Mr}$. Agusnimar, Interview, as one of the parents who runs his parents' estate on 23 July 2017.
3. Syirkah Implications Amlak in building economic independence, including: Level of education, level of income, level of labor, increase in home industry, level of religiosity (obedience to God), and level of welfare (al-Falah)

\section{REFERENCES}

1. Departemen Agama RI, Al-Quran Dan Terjemahannya, (Bandung: PT Diponogoro, 2014).

2. Acho-chi, C. 1998. "Sustainable self-development efforts in Cameroon grass fields." Development in Practice, 8(3).

3. Ahmad, Khurshid. Studies in Islamic Economics. (Leicester, U.K: The International Centre for Research in Islamic Foundation, 1980).

4. Algaoud, Mervyn K. Lewis dan Lativa M. Islamic Banking. (Massachusetts: Edward Elgar, 2001).

5. al'Alim, Yusuf Hamid. al-Maqashid al-'Ammah Li al-Syari'ah alIslamiyah, (Horndon: al-Ma'had al- 'Alami Li al-Fikiri al-Islamy, 1991).

6. Avilliani. Kemandirian Ekonomi. (UIN: Institute for Development of Economics and Finance. 2012).

7. Chapra, M. Umer (1985), Towards a Just Monetary Sistem. Terj. Ismail bin Omar. Kearah Sistem Kewangan yang Adil. (Kuala Lumpur: Dewan Bahasa dan Pustaka, 1990).

8. Collins, W. A., Gleason, T., \& Sesma, A. Jr., 1997, Internalization, Autonomy, and Relationships: Development during Adolescence. dalam J. E. Grusec \& L. Kuczynski (Eds.), Handbook of Parenting and the Transmission of Values (New York: Wiley, 1997).

9. Fonchingong, C.C., dan Fonjong, Lotsmart. N. (2003). "The Concept of Self-Reliance in Community Development Initiatives in The Cameroon Grassfields". Nordic Journal of African Studies, Vol. 12(2).

10. Galtung, J. et al. (eds.). Self-Reliance: a Strategy for Development. (London: Bogle L'Ouverture publications. 1980)

11. Gooneratne, W. and Mbilinyi, M. (eds.) 1992. "People's Responses to the Economic Crisis in Eastern and Southern Africa.” Reviving Local Self-Reliance. UNCRD, Japan.

12. Haroen, Nasrun. Figh Muamlah. (Jakarta: Gaya Media Pratama, 2000).

13. Hubeis, H.V.S. (2002). Tantangan dan Prospek Teknologi Informasi dan Komunikasi dalam Otonomi Daerah. Dalam Pambudy, R., dan Adhi, A.K. (ed). Pemberdayaan Sumber Daya Manusia Menuju Terwujudnya Masyarakat Madani, (Bogor: Pustaka Wirausaha Muda,tt).

14. Hyden, G. No Shortcuts to Progress: African Development Management in Perspective. (London: Heinemann, 1983)

15. Idoma Kim, Muhammad Isma'il, "Self-Reliance: Key to Sustainable Rural Development in Nigeria", ARPN Journal of Science and Technology, VOL. 3, NO. 6, June 2013.

16. Ismail, Muhammad Syah. Falsafah Hukum Islam, (Jakarta: Bina Aksara, 1992).

17. al-Iwadhi, Rif'at Sayyid. Kitab al-Ummah fi al-Istishad al-Islamy alMurtakaza al-Tauzi' al-Istimar.

18. Kahf, Monzer. "Islamic Economic System - A Review" dalam Aidit Ghazali dan Syed Omar (ed), Reading in The concept and Methodology of Islamic Economics. (Pataling Jaya: Pelanduk Publications, 1989).

19. Khalaf, Abdul Wahab. Mashadir al-Tasyri' fi Ma la Nashsha Fiki, (Ttp: Ma'had al-Dirazah al-A'rabiyah).

20. Khaldun, Abdur Rahman Ibn. Mugaddimah, (Ttp: Matbaah alAzhariyah, $1348 \mathrm{H})$.

21. Mannan, M. A. Islamic Economics; Theory and Practice, (Cambridge: Houder and Stoughton Ltd, tt).

22. Mustaqim, Rizal. "Kemandirian Dan Pemberdayaan Ekonomi Berbasis Pesantren (Studi Atas Peran Pondok Pesantren Al-Ittifaq Kecamatan Rancabali Kabupaten Bandung Terhadap Kemandirian Eknomi Santri Dan Pemberdayaan Ekonomi Masyarakat Sekitarnya)", dalam Jurnal Ekonomi Syari'ah Indonesia. Volume I, No.2 Desember 2011.

23. Mu'tadin, Zainun (2002), Kemandirian Sebagai Kebutuhan Psikologis pada Remaja, http://www.e-psikologi.com/epsi/search.asp, diakses tanggal 27 April 2017.

24. An-Nabahan, Faruq. Sistim Ekonomi Islam: Pilihan Setelah Kegagalan Sistim Kapitalis dan Sosialis, (Yogyakarta: UII Press, 2000). Cetakan Kedua. 
25. Njoh, A. 2002. "Barriers to Community Participation in Development Planning: Lessons from the Mutengene (Cameroon) Self-help Water Project." Community Development Journal, 37(3).

26. Ojameruaye, E. "Strategies for Self-reliant Economic Development of Urhobo land: A Paper Presented at the 5th Annual Conference of Urhobo Historical Society at PTI Conference Centre”. Effurun, Delta: 2004.

27. Pradja, Juhaya S. Ekonomi Syariah, (Bandung: Pustaka Setia, 2012)

28. Pronk, Jan. "Globalization: A Developmental Approach", dalam Jan Nederveen Pieterse (ed), Global Future, Shaping Globalization, (London: Zed Books, 2001).

29. al-Risuni, Ahmad. Nadhariyah al-Maqasid 'Inda al-Imam al-Syatibi, (Virginia: The International Institute of Islamic Thought, 1995).

30. Rofiq, Romdin A., A. Icep Fadlil Yani dan R.B. Widodo, Pemberdayaan Pesantren Menuju Kemandirian dan Profesionalisme Santri dengan Metode Daurah Kebudayaan, (Yogyakarta: Pustaka Pesantren, 2005)

31. Sabiq, Sayyid. Figih Sunnah, Terj. Kamaluddin A. Marzuki, (Bandung: Al Ma'arif, 1988)

32. Saddiqi, Muhammad Nejatullah. Muslim Economic Thinking: A Survey of Contemporary Literature. (Leicerter, United Kingdom: The Islamic Foundation, 1989).

33. ash Shawi, Abdullah al Mushlih dan Shalah. Fikih Ekonomi Keuangan Islam, terj. Abu Umar Basyir. Judul asli: Ma ia Yasa'ut Tajiru Jahluhu, (Jakarta: Darul Haq, 2004).

34. Shomedran, (2016), "Pemberdayaan Partisipatif Dalam Membangun Kemandirian Ekonomi dan Perilaku Warga Masyarakat (Studi Pada Bank Sampah Wargi Manglayang RT 01 RW 06 Kelurahan Palasari Kecamatan Cibiru Bandung)”, http://ejournal.upi.edu/index.php/pls/article/view/3086, diakses: tanggal 5 Mei 2017.

35. Sumodiningrat, Gunawan. Pemberdayaan Masyarakat dan Jaring Pengamanan Sosial, (Yogyakarta: Ghalia Indonesia, 1999).

36. Suryono, Agus. Pengantar Teori Pembangunan, (Malang: Universitas Negeri Malang, 2004). 